DOI 10.22460/infinity.v5i2.218

\title{
LEARNING MEDIA DEVELOPMENT APPROACH WITH A RECTANGLE PROBLEM POSING BASED GEOGEBRA
}

\author{
Bagus Ardi Saputro \\ Mathematics Education PGRI Semarang University, Jalan Didodadi East Java, Indonesia \\ bagusardisaputro@yahoo.co.id
}

Received: June 28, 2016; Accepted: July 18, 2016

\begin{abstract}
This study aims to develop learning media quadrilateral with problem posing approach based GeoGebra. 8 teachers from three different schools have stated that this media can be used to teach the nature - the nature of the quadrilateral. After the learning is done using this media, this media can facilitate students in asking about the nature - the nature of wake quadrilateral, facilitating students to learn the relationship between the type - the type of wake rectangles that have the same properties, and provides the opportunity for teachers in the evaluation of mathematical communication current students ask and write.
\end{abstract}

Keywords: Rectangular, Problem Posing, GeoGebra

\begin{abstract}
Abstrak
Penelitian ini bertujuan untuk mengembangkan media pembelajaran segiempat dengan pendekatan problem posing berbasis GeoGebra. 8 guru dari 3 sekolah yang berbeda telah menyatakan bahwa media ini dapat digunakan untuk mengajarkan sifat - sifat segiempat. Setelah pembelajaran dilakukan menggunakan media ini, media ini dapat memfasilitasi siswa dalam bertanya tentang sifat - sifat bangun segiempat, memfasilitasi siswa belajar hubungan antara jenis - jenis bangun segiempat yang mempunyai sifat yang sama, dan memberikan kesempatan kepada guru dalam melakukan evaluasi tentang komunikasi matematis siswa saat bertanya dan menulis.
\end{abstract}

Kata Kunci: Segi Empat, Problem Posing, GeoGebra

How to Cite: Saputro, B.A. (2016). Learning Media Development Approach with a Rectangle Problem Posing Based Geogebra. Infinity, 5 (2), 121-130

\section{INTRODUCTION}

Quadrilateral is one of the study materials in the junior that is considered difficult by students (Akhsani, Sukestiyarno \& Wiyanto, 2012; Rumiah, \& Darminto, 2015; Disnawati, Hartono \& Putri, 2015). This is shown by the low learning outcomes in the material quadrilateral (Aryanti, Zubaidah \& Nursangaji, 2013; Rumiah, \& Darminto, 2015). Flat material absorptive capacity in some areas such as in Pacitan, Banyumas, Kebumen and also low (Son, 2014; Fadlilah, Usodo \& Subanti, 2015; Miftachudin, Budiyono \& Riyadi, 2015). The problems arise because of several factors such as: (1) students tend to be passive in receiving a lesson, namely to listen and pay attention to the teacher (Akhsani, Sukestiyarno \& Wiyanto, 2012; Setyaningsih, Darminto, \& Purwoko, 2013; Sasmi, Aima \& Fitri, 2014; Octavianti Setiawan \& Trapsilasiwi, 2014), (2) the students used to memorize concepts, but can not yet understand the concept (Yusuf, Zulkardi \& Saleh, 2009; Sasmi, Aima \& Fitri, 2014; Octavianti, Setiawan \& Trapsilasiwi, 2014), (3) students rarely ask if any part of the material that is not yet 
understood (Putra, 2014), (4) students tend to be fearful and reluctant to answer questions provided by the teacher (Putra, 2014), (5) a lot of students who do not understand the material prerequisites (Putra, 2014 ), (6) when no homework or quizzes, students are less confident in their ability, they are lazy to think for themselves, the students enjoy asking her about material presented teacher (Rumiah \& Darminto, 2015), (7) the student has not skillfully use tool - the tool geometry such as the length and arc (Sukayasa, 2014), (8) students are less able to identify the properties - properties of the rectangle with the right, so it can not organize the linkages between wake by nature - and nature (Wulansari \& Rosyidi, 2013).

The cause of the problem as: learning methods are used mostly still is direct / mechanistic (Putra, 2014), teachers are just giving an example of completion of a problem by using a formula that is suitable and not yet using the form - the form of other representations (Aryanti, Zubaidah \& Nursangaji, 2013), delivery of content quadrilateral only use images created on the board using chalk (Akhsani, Sukestiyarno \& Wiyanto, 2012; Dwijayanti, 2012), teachers rarely pay attention to the potential, creativity and imagination of the students (Yusuf, Zulkardi \& Saleh, 2009; Dwijayanti 2012, Suyadi, 2015), the issue - given problem has only one solution, so it does not facilitate the ability of divergent thinking (Yusuf, Zulkardi \& Saleh, 2009).

Efforts suggested in this problem are: Education should provide experience to students to give examples - examples that are not monotonous, and emphasis on nature - the nature of the quadrilateral (Wulansari \& Rosyidi, 2013), attention to student motivation (Awaliyah, 2015) and attention to the selection models and methods appropriate to the material (Setyaningsih, Darminto \& Purwoko, 2013; Ruminah \& Darminto, 2015; Suryadi, 2015), trained from an early age to express ideas or opinions with many asking questions that could provoke the power of reason students (Indahwati, 2015), using the method of problem solving (Hidayat, 2014), using open-ended questions (Yusuf, Zulkardi, \& Saleh, 2009).

Innovation in accordance with suggestions to solve these problems is the use of the modelbased learning problem posing GeoGebra. By using problem posing student achievement will be better (Haji 2011; Susanti, Sukestiyarno, \& Sugiharti, 2012; Robiah, 2013), understanding of mathematical concepts and understanding about the students will be better (Herath, Siroj \& Basir, 2010; Haji, 2011). Problem posing approach also provides an opportunity for students to convey (formulate), forming and asking a simple question or situation based on the information provided in order to solve a complex problem (Haji 2011; Herath, Siroj, \& Basir, 2010). By using GeoGebra then (1) painting - painting geometry generated faster than using a pencil, ruler and compass, (2) can be animated and moved by dragging on the object geometries that provide a visual experience, (3) be used as a feedback / evaluation make sure the paintings are made correctly, (4), enables teachers / students to investigate or show properties -sifat that apply to an object geometry (Mahmudi, 2010), increasing the ability to think critically (Ariawan, 2012), to facilitate students to try out, observe, reason and find the idea of an idea - the idea of mathematical (Saputro, Prayito, \& Nursyahidah, 2015). Therefore, this study sought to develop learning media rectangular-based approach to problem posing GeoGebra.

\section{METHOD}

This study is one part of the implementation of the research methods Research and Development (R \& D) is a test of learning media first. Subjects were junior high school students from several schools in Brebes Central Java province of Indonesia. The instrument 
used in this study a quadrilateral instructional design approach based GeoGebra problem posing, interview guides, observation sheets incorporating sound recording device and image recording. Interviews were conducted to the junior high school math teacher who was and is teaching material quadrilateral.

\section{RESULTS AND DISCUSSION}

\section{Results}

Development of instructional media quadrilateral with problem posing approach based GeoGebra produce three media with the same initial appearance is as shown in Figure 1.

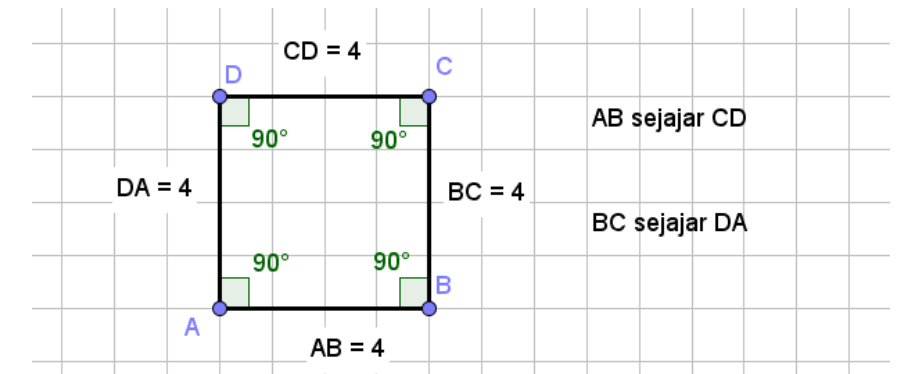

Figure 1. Media Problem Posing

Media created by selecting properties - special properties so wake quadrilateral has a special name. Property that is used to construct one corner is the elbow - the elbow, a pair of opposite sides are parallel, and a pair of side coincides same length. Of these three properties, they invented the three wake quadrilateral. Every waking quadrilateral is a situation that can raise many questions. Questions - questions that the students will be selected by the teacher to be discussed in the classroom. Selected questions are questions that provide an understanding of the nature - the nature of the quadrilateral wake.

The media also comes with an information sheet about the nature - the nature of all wake quadrilateral and student worksheet as media usage instructions. Illustrations contained in the information sheet on purpose to be served by special properties possessed by a square, rectangular, trapezoid, parallelogram, kiteand rhombus. So that students easily understand the peculiarities of each type of the quadrilateral. Student worksheets are designed so that students understand the wake like what they discover. Then give the freedom to explore. Exploration concludes with the question - the question that will be posed to the class.

\section{Discussion}

\section{a. Design Validation}

Responses math teacher secondary school to study media quadrilateral, namely (1) teacher teacher young mathematician with teaching experience of less than 6 years tend to reject the use of this media, it is because they think students - they are incapable of learning with media and approach problem posing. They would suggest that the media is to be used in the classroom and the high caliber students who are already accustomed to using the computer as a media of learning. (2) teacher - a teacher of mathematics with teaching experience of more than 13 years tend to be happy and want to use this media, only a few schools they do not have a computer lab facilities so that most of them feel sad not been able to use this media in a math class. However the teacher - the teacher agrees that the instructional media 
quadrilateral with GeoGebra-based approach to problem posing can be used to teach the nature - the nature of the quadrilateral wake.

\section{b. Trial Media Learning}

In the pilot study, the size of which is always fixed for the first media is a corner that has a $90^{\circ}$ angle measure. All groups responded that the angle $\mathrm{A}$ is always fixed at $90^{\circ}$. But for the next question is what are the rectangles that can be formed when shifting points $\mathrm{A}, \mathrm{B}, \mathrm{C}$, and $\mathrm{D}$, each group has a different answer. The answer from each group are presented in Table 1 .

Table .1. Recap Answer Question No. 2

\begin{tabular}{lccccc}
\hline \multirow{2}{*}{ Rectangular types } & \multicolumn{9}{c}{ Group } \\
& A & B & C & D & E \\
\hline Square & $\sqrt{ }$ & $\sqrt{ }$ & $\sqrt{ }$ & $\sqrt{ }$ & $\sqrt{ }$ \\
Rectangle & $\sqrt{ }$ & $\sqrt{ }$ & $\sqrt{ }$ & $\sqrt{ }$ & $\sqrt{ }$ \\
Kite & & $\sqrt{ }$ & & & \\
Trapezoid & $\sqrt{ }$ & $\sqrt{ }$ & $\sqrt{ }$ & & $\sqrt{ }$ \\
rhombus & & & & & \\
Parallelogram & & & & & \\
\hline Description: $\sqrt{ }=$ formed & & & & &
\end{tabular}

When teachers see students' answers that have been in the recap answer each group presented on teble 1 . Then the teacher can understand that some squares are not formed when the first media used. Therefore, by using the LCD screen, the teacher with students can try, if true rectangle is indeed not formed. Once tested, the trapezoid turns can be formed easily. But because the group D do not understand the nature of your trapezoid that has a pair of opposite sides parallel, then the group did not get a trapezoid. Kite can also be formed. Kite formed is the kite with one of its corners is $90^{\circ}$.

When discussing the wake kite. By shifting point $\mathrm{C}$ towards point $\mathrm{A}$, it will obtain the square wake. Students look at the size of the $\mathrm{AB}=\mathrm{DA}$ and $\mathrm{BC}=\mathrm{CD}$, which is a condition called quadrilateral kite.

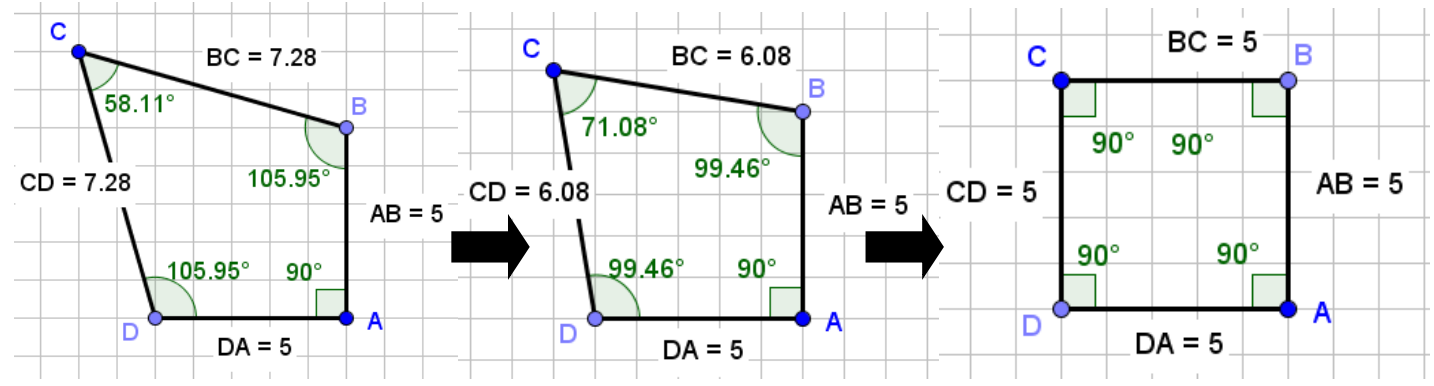

Figure 2. Square is a kite 
Communication between teachers and students

Teacher: Kite assume the character has two pairs of adjacent sides equal in length. Square also has two pairs of adjacent sides equal in length. So the square can be referred to as kite.

Student: I do not agree the teacher!

Teacher: Why do you disagree?

Student: It's square instead of kite.

Teacher: Quadrilateral also has two adjacent sides of the same length. So there is no problem we say that the square is the kite.

From the question no 3 obtained 28 questions. Question - this question consists of 15 questions about the quadrilateral and 13 questions instead of rectangular. The question is not about the quadrilateral consists of 8 questions about the technical use of media created, and 5 questions about the matter to another. Questions about the quadrilateral consisting of nine questions about forming a quadrilateral and 6 questions about the nature - the nature of the quadrilateral. All questions asked by the students are presented in Table 2.

Table 2. Recap Questions from Group 5

Questions about the technical use of media
1. A corner why can not shift when making a parallelogram?
2. Why can shift the angle B but could just up and down?
3. Why the corner A has only $90^{\circ}$ size?
4. Why A corner can not be moved?
5. Why is the angle B can not be in the right direction?
6. Why can not the angle B to the left?
7. Why quadrilateral retains $90^{\circ}$ size?
8. Why A corner can not be shifted?

\section{Questions about other materials}

1. If the angle B is pulled to the angle A will be arbitrary triangle.

2. What is the side that is owned by a circle?

3. What is the degree possessed angle isosceles triangle?

4. Why is angle - elbow length $90^{\circ}$ ?

5. How many sides a triangle?

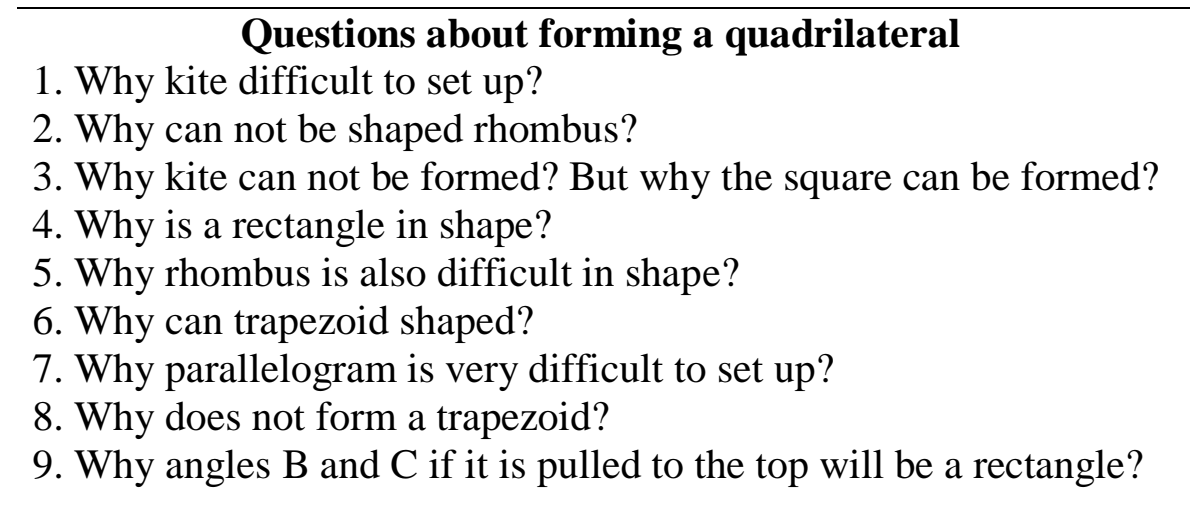




\section{Questions about the nature - the nature of the quadrilateral}

1. Why wake the same square with rhombus?

2. Why has the size $90^{\circ}$ square corners?

3. Why the rectangles are facing the same length?

4. Why does a trapezoid have a pair of parallel sides?

5 . Why rhombus has four sides of equal length?

6. Why kite have two sides of the same length?

When teachers get questions that relate the other material. Teachers can, say that, we are learning about the rectangle, so we can not answer the question it. Later we discuss the question after this study was completed. Meanwhile, when the students started asking questions about the properties of the quadrilateral. Here is your chance to answer the teacher and explain the properties - properties of the quadrilateral and the relationship between the type - the type of quadrilateral. One interesting question is why the building of the student square equal to a rhombus? Answer this question is because a square has the same properties as the rhombus which has four sides of equal length. Teachers can use the media to demonstrate what a second is to create a square with sides of 5 units. Then shift the point $\mathrm{D}$ to get $90^{\circ}$ angle and shift the point $\mathrm{C}$ to get side - the side length 5 units. It concluded that a square is a rhombus whose angle $90^{\circ}$. Such a process can certainly be done for other types of quadrilateral.

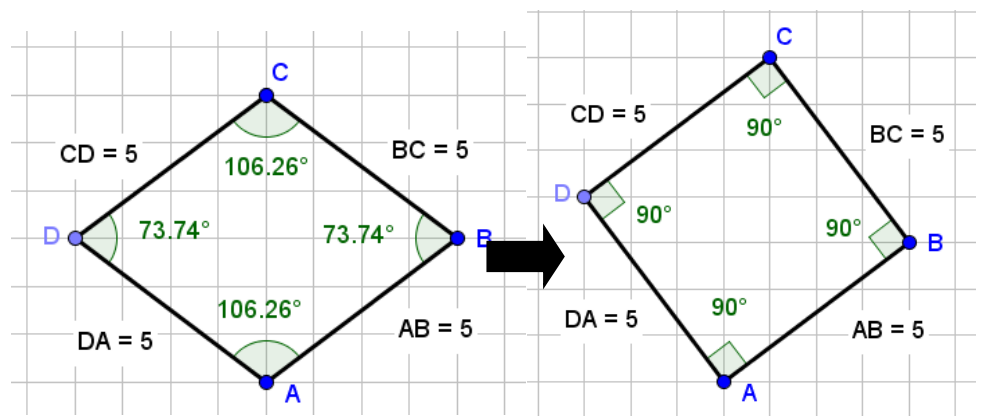

Figure 3. A square is a rhombus

Most of the questions asked by the students have the same characteristics, namely using the question word "why". This question word indicates the student has a high curiosity. This allows students organize the relationship between each type of rectangular by nature - nature.

The obstacles encountered by teachers for use student learning media are not used to using a computer mouse is in use. So that students are less adept at shifting point. Students also often do so make the scroll to be great. This is an excellent input for the revision process of this learning media is to turn off all GeoGebra tool unless the tool transfer. Media first, second and third will be one to make it more efficient. The findings that are useful for teachers is the teacher can correct the students' mathematical communication is not right when the students express their opinions by speaking and writing.

At the end of learning, the teacher asks the students to write down their thoughts on the learning that has been done. The result is all the group was pleased to learn the instructional media quadrilateral with problem posing approach based GeoGebra. Some of those reasons are: 
"Glad to study with a friend for help each other and feel easy because it uses leptop".

"This type of learning is actually fun and easy to understand. Because even though the material is solid, it is very easy for us to understand ".

"I think the fun way of teaching".

"I am pleased to learn together - together to discuss about mathematics".

"We are pleased to learn together because it is easier and fun, although a bit complicated".

They also write the difficulties and feelings they experienced during the learning takes place. Difficulties they include:

"The difficulty for us when we shift and make the question"

"Not happy because it is rather difficult because sedikt scramble and noisy"

"The bad news is our own class commotion"

"That makes it difficult to learn is by clicking on his laptop"

"The explanation is less obvious"

Student difficulties in learning are invaluable advice in using this media. Some things that might be considered is the number of students per group, students' skills in using computers, classroom management and clear communication from teacher to student.

\section{CONCLUSION}

From the trial learning in the classroom, can be obtained by several things, among others (1) instructional media quadrilateral with problem posing approach based GeoGebra can facilitate students to ask questions and express opinions, (2) can be used to demonstrate visually the relationship between the type - the type of quadrilateral has the same properties, (3) and can be used by teachers in the evaluation of mathematical reasoning, mathematical communication when students ask and write.

\section{REFERENCES}

Akhsani, L., Sukestiyarno \& Wiyanto (2012). Pengembangan Perangkat Pembelajaran Matematika dengan Metode CIRC Berbasis Membaca Berbantuan CD Interaktif Materi Segiempat Kelas VII. Unnes Journal of Mathematics Education Research, 1(1).

Ariawan, I. P. W. (2012). Pengembangan Model dan Perangkat Pembelajaran Geometri Bidang Berbantuan Open Software Geogebra. JPP Undiksha, 45(2).

Aryanti, D., Zubaidah \& Nursangaji, A. (2013). Kemampuan Representasi Matematis Menurut Tingkat Kemampuan Siswa Pada Materi Segi Empat di SMP. Jurnal Pendidikan dan Pembelajaran, 2(1). 
Awaliyah, K. (2015). Eksperimentasi Model Pembelajaran ARIAS pada Materi Segiempat Ditinjau dari Motivasi Belajar Siswa Kelas VII SMPN 2 Mirit Tahun Pelajaran 2013/2014. EKUIVALEN-Pendidikan Matematika, 16(1).

Disnawati, H., Hartono, Y., \& Putri, R. I. I. (2015). Eksplorasi Pemahaman Siswa dalam Pembelajaran Bangun Datar Segi Empat di SD Menggunakan Konteks Cak Ingkling. Pythagoras, 7(2).

Dwijayanti, I. (2012). Pengembangan Perangkat Pembelajaran Matematika Humanistik Berbasis Konstruktivisme Menggunakan ICT Materi Segi Empat Kelas VII. AKSIOMA, 2(2/September).

Fadlilah, U., Usodo, B., \& Subanti, S. (2015). Eksperimentasi Model Pembelajaran Problem Based Learning (Pbl) Dan Discovery Learning (Dl) Dengan Pendekatan Saintifik Pada Materi Segiempat Ditinjau Dari Kecemasan Belajar Matematika Siswa SMP Negeri Kelas VII di Kabupaten Banyumas. Jurnal Elektronik Pembelajaran Matematika. 3(8).

Haji, S. (2011). Pendekatan Problem Posing dalam Pembelajaran Matematika di Sekolah Dasar. TRIADIK, 14(1), 55-63.

Herawati, O. D. P., Siroj, R. A., \& Basir, M. D. (2010). Pengaruh Pembelajaran Problem Posing Terhadap Kemampuan Pemahaman Konsep Matematika Siswa Kelas XI IPA SMA Negeri 6 Palembang. Jurnal Pendidikan Matematika, 4(1), 70-80.

Hidayat, W. (2014). Eksperimentasi Pembelajaran Matematika Menggunakan Metode Problem Solving Materi Segitiga dan Segi Empat Terhadap Prestasi Belajar Siswa Kelas VII Semester II Mts Grogol Penatus Kabupaten Kebumen Tahun Pelajaran 2012/2013. EKUIVALEN-Pendidikan Matematika, 9(1).

Indahwati, R. (2015). Penerapan Model Pembelajaran Diskusi Kelas Dengan Pemecahan Masalah Matematika Kontekstual Untuk Meningkatkan Kemampuan Berpikir Kritis Siswa Pada Materi Segi Empat Di Kelas VII SMP Negeri 4 Pamekasan. Jurnal Kependidikan Interaksi, 20(1)

Mahmudi, A. (2010). Membelajarkan Geometri dengan Program GeoGebra. In Prosiding Seminar Nasional Matematika dan Pendidikan Matematika (2010):” Peningkatan Kontribusi Penelitian dan Pembelajaran Matematika dalam Upaya Pembentukan Karakter Bangsa”. Jurusan Pendidikan Matematika FMIPA UNY.

Miftachudin, M., Budiyono, B., \& Riyadi, R. (2015). Efektivitas Model Pembelajaran Two Stay Two Stray Dengan Tutor Sebaya dalam Pembelajaran Matematika pada Materi Bangun Datar Ditinjau dari Kecerdasan Majemuk Peserta Didik Kelas VII SMP Negeri di Kebumen Tahun Pelajaran 2013/2014. Jurnal Elektronik Pembelajaran Matematika. 3(3) 
Octavianti, F., Setiawan, T. B., \& Trapsilasiwi, D. (2014). Penerapan Pembelajaran Kooperatif Tipe Team Assisted Individualization (TAI) untuk Meningkatkan Hasil Belajar pada Sub Pokok Bahasan Keliling dan Luas Bangun Segitiga dan Segi Empat Siswa Kelas VII D SMP Negeri 1 Ajung Semester Genap Tahun Ajaran 2012/2013. Pancaran Pendidikan, 3(1), 121-130.

Putra, A. P. (2014). Eksperimentasi Pendekatan Pembelajaran Matematika Realistik (PMR) dan Pendekatan Pembelajaran Open Ended Pada Materi Segitiga dan Segiempat Ditinjau dari Gaya Kognitif Siswa Kelas VII SMP Negeri se-Kabupaten Pacitan. Numeracy, 1(2).

Robiyana, A. (2013). Eksperimentasi Pembelajaran Matematika Menggunakan Model Problem Posing Materi Segitiga Kelas VII Semester Genap SMP Negeri 16 Purworejo Tahun Pelajaran 2011/2012. EKUIVALEN-Pendidikan Matematika, $3(1)$.

Rumiah, T. \& Darminto, B.P. (2015). Studi Komparasi Prestasi Siswa Antara Model Pembelajaran Reciprocal Teaching dan Direct Instruction dalam Materi Segiempat. EKUIVALEN-Pendidikan Matematika, 18(2).

Saputro, B. A., Prayito, M., \& Nursyahidah, F. (2015). Media Pembelajaran Geometri Menggunakan Pendekatan Pendidikan Matematika Realistik Berbasis GeoGebra. Kreano, Jurnal Matematika Kreatif-Inovatif, 6(1).

Sasmi, F. D., Aima, Z. \& Fitri, D.Y. (2014). Pengembangan LKS Berbasis Guided Discovery (Penemuan Terbimbing) pada Pokok Bahasan Bangun Datar Segi Empat Kelas VII Semester 2 Mts Lunto Kota Sawahlunto. Pendidikan Matematika, 4(2).

Setyaningsih, A. Darminto, B.P. \& Purwoko, R.Y. (2013). Eksperimentasi Model Pembelajaran Tipe NHT pada Pokok Bahasan Segi Empat Terhadap Prestasi Belajar Matematika Siswa Kelas VII Mts Negeri Prembun. EKUIVALENPendidikan Matematika, 3(1).

Sukayasa, S. (2014). Peningkatan Pemahaman Siswa SD Karunadipa Palu Terhadap Konsep Bangun-Bangun Segiempat Melalui Pembelajaran Model Pencapaian Konsep. Media Eksakta, 2(2).

Susanti, E. L., Sukestiyarno, Y. L., \& Sugiharti, E. (2012). Efektivitas Pembelajaran Matematika Dengan Metode Problem Posing Berbasis Pendidikan Karakter. Unnes Journal of Mathematics Education, 1(1).

Suyadi, H. M. (2015). Peningkatan Hasil Belajar Siswa Melalui Penerapan Model Pembelajaran Jigsaw Pada Materi Pokok Segitiga dan Segi Empat Kelas VII H SMP Negeri 21 Semarang Tahun Pelajaran 2013/2014. Media Penelitian Pendidikan, $8(1$ juni).

Wulansari, A., \& Rosyidi, A. H. (2013). Profil Pengetahuan Konseptual Siswa SMP di Jenjang Proses Kognitif Menganalisis Pada Materi Segi Empat Berdasarkan Jenis Kelamin. Kreano, Jurnal Matematika Kreatif-Inovatif, 4(2), 174-181. 
130 Saputro, Learning Media Development Approach ...

Yusuf, M., Zulkardi, Z., \& Saleh, T. (2009). Pengembangan Soal-Soal Open-Ended pada Pokok Bahasan Segitiga dan Segiempat di SMP. Jurnal Pendidikan Matematika, $3(2), 48-56$. 